\title{
Creating cultural refugia to transform the boundaries of science
}

\section{Marijke Hecht ${ }^{1}$ (D)}

Received: 18 September 2020 / Accepted: 3 November 2020 / Published online: 17 May 2021

(c) Springer Nature B.V. 2021

\begin{abstract}
This paper is a reflection on Bobby Habig, Preeti Gupta, and Jennifer Adams' article Disrupting deficit narratives in informal science education: Amplifying community cultural wealth theory to youth learning and engagement. The article examines the significance of community cultural capital and the need for informal STEM institutions to engage more deliberately with the knowledge and lived experiences that youth bring to programs they participate in. In my response, I question whether the informal science institution of study had changed in response to these young people. As a 'science insider,' I explore how research experiences in informal science education institutions such as museums are tightly bounded by and connected with ancient European scientific practices that limit a deep embrace of community cultural wealth. If the aim is for youth to develop their science identities, then these informal science education institutions need to question what kind of science people they are asking youth to become. I consider how informal science education institutions might remake themselves as cultural refugia, where interrogation of the dominant Eurocentric norms of what science is can be challenged and transformed.
\end{abstract}

Keywords Science identity $\cdot$ Informal science education $\cdot$ Refugia

\section{Crear refugia cultural para transformar los límites de la ciencia}

\section{Resumen}

Este documento es una reflexión en torno al artículo de Bobby Habig, Preeti Gupta y Jennifer Adams, Disrupting deficit narratives in informal science education: Amplifying community cultural rote theory to youth learning and engagement. El artículo examina la im-

Lead Editor: Cassie Fay Quigley.

This review essay addresses issues raised in Habig, Gupta, and Adams' paper entitled: Disrupting deficit narratives in informal science education: Amplifying community cultural wealth theory to youth learning and engagement (https://doi.org/10.1007/s11422-020-10014-8).

Marijke Hecht

marijke@psu.edu

1 Recreation Park and Tourism Management, Penn State Greater Allegheny, Frable Building, 201C, 4000 University Drive, McKeesport, PA 15132, USA 
portancia del capital cultural comunitario y la necesidad de que las instituciones informales de STEM se involucren de manera más deliberada con el conocimiento y las experiencias vividas que los jóvenes aportan a los programas en los que participan. En mi análisis, me pregunto si la institución de ciencia informal que estudio ha cambiado en respuesta a estos jóvenes. Como "conocedora de la ciencia," exploro cómo las experiencias de investigación en las instituciones educativas científicas informales están estrechamente vinculadas a antiguas prácticas científicas europeas que limitan una aceptación profunda de la riqueza cultural de la comunidad. Si el objetivo es que los jóvenes desarrollen sus identidades científicas, entonces estas instituciones educativas científicas informales deben preguntarse en qué tipo de personas científicas esperan convertir a los jóvenes. Finalmente, considero cómo las instituciones educativas científicas informales podrían transformarse en refugias culturales, donde las normas eurocéntricas dominantes de lo que es la ciencia pueden ser cuestionadas, desafiadas y transformadas.

Keywords Identidad científica $\cdot$ Educación informal de la ciencia $\cdot$ Refugia

It was early spring 2020 when I was asked to reflect on Bobby Habig, Preeti Gupta, and Jennifer Adams' article Disrupting deficit narratives in informal science education: Amplifying community cultural wealth theory to youth learning and engagement. And then the spring unfolded. First, I found myself cloistered and physically distant from friends, family, and colleagues, hiding from the global COVID-19 pandemic. Then, suddenly, I was walking cheek to jowl with thousands of people as my city, like so many, erupted in protests over ongoing police violence against Black people in the USA. When I was able to return to this reflective piece, I found myself thinking about connections between the challenge that Habig, Gupta, and Adams raise - the need for informal science educators and institutions to embrace and nurture the rich community wealth that youth carry-and the twin pandemics consuming my thinking and being. At the heart of addressing all of these challenges is a need for us to engage in radically reimagining our society, to walk through the 'portal' into a new, more just world (Roy 2020).

The Habig, Gupta, and Adams article examines the significance of community cultural capital and the need for informal STEM institutions to engage more deliberately with the knowledge and lived experiences that youth bring to programs they participate in. The authors focus on three participants of a multi-year informal science program based at the American Museum of Natural History. Through multiple interviews over several years, Habig, Gupta, and Adams explore how these individuals navigated their experiences in the program and then in their college years and early careers. They specifically examine the ways that the participants drew on their community cultural wealth in order to become science people. Factors that supported this process for the youth included both experiential program elements (e.g., experiences that expanded the realm of possibilities for youth; a continuum of STEM experiences that they were able to draw on) and interpersonal factors (e.g., building sustained networks in the STEM community; drawing on their cultural wealth to exhibit resilience in the face of obstacles to success). These young people, through both challenging and well-supported paths, ultimately find their way into the science community.

As I read their article, however, I found myself ruminating on whether the science community or science as a discipline had changed in response to these young people. The complexity for informal science educators and institutions that claim to be working toward an 
equitable scientific community is how to expand participation without forcing assimilation to dominant norms. This surfaces an inherent tension in the goals for equity and justice in science education-ideally, science education programs facilitate youth entrance into existing and tightly bounded scientific disciplines at the same time they help youth push at the edges and expand those boundaries. This means that on the one hand, informal science programs must be designed to expose youth to the language, culture, and practice of science in order to prepare them for success in the field, while on the other hand, they must equip youth to challenge those very institutional structures.

I have been wrestling with this tension throughout my career, first as a science educator and later as an educational researcher. The American Museum of Natural History is, like many informal science education institutions, best prepared to do the former. But to only do the former, without the latter, undermines real transformation for equity and justice within the scientific community. For that, we must reimagine and recreate the boundaries of science and change the essence of the scientific community itself.

I write here as a 'science insider' (Dawson 2014b). I have been trained, from elementary school through my graduate studies, using the tools of Eurocentric scientific disciplines. I have deliberately chosen to use the word Eurocentric, rather than Western, to characterize the dominant scientific paradigm. The imaginary geography of Europe as "The West" ignores that much of Africa is due south and equally west and that all of the Americas are to the west of Europe. The phrase Western Science reinforces an implicit centering of European thought, while Eurocentric makes this centering explicit and contestable.

I have spent the majority of my life living in the USA and have adopted dominant US norms, made relatively easy for me by virtue of the fact that I am a white woman. When I began my career as a public-school math and science teacher nearly 25 years ago, I was primarily focused on finding ways for my students to enter science fields. It was not until more than a decade later, when I was an informal science educator using urban parks as classrooms, that I slowly began to recognize the flaws inherent in this approach. Working in this out-of-school space, I found that I got to know the youth in a different way than I ever did as a classroom teacher. Their personal interests, home lives, and communities were all regular topics of conversation that entered our discussions as we flipped rocks looking for salamanders or carried logs for erosion control and trail building. These experiences forced me to begin to dismantle many of my own views about what does and does not count as science. My evolving thinking is mapped as questions on sticky notes over my desk, marginal notes in my readings, and in discussions with colleagues that bend and frustrate. The dismantling of what science is is an ongoing process for me.

I also write drawing on ideas and insights born out of conversations with two other women educators, playmakers, learning instigators, and earth troublemakers. In early April, the three of us had a twitter exchange about our shared desire to connect education more with local places. This developed into weekly Zoom conversations (the go-to pandemic gathering space) that began on April 1, 2020 and continue to this day. We developed our own curriculum for these conversations-questions, readings, music, laughter, and the practice of walking and reflecting. We named our experiment \#WalkingAloneandTogether and it has heavily influenced many of the ideas included in my comments here. My co-conspirators-Michelle King and Shimira Williams - are essential elements of my own community cultural wealth. Michelle King taught middle school history for 22 years and now, as a learning instigator and love activist, works in partnership with regional organizations to create equitable and empathetic learning opportunities for children and adults. Shimira Williams works at the intersection of early childhood and technology, working to build digital citizens through play and productivity. 
Together we have created a refugium, a protected place where our ideas can flourish and our bodies can thrive despite the unfavorable conditions in the larger world (King and Williams, personal communications, April 1-September 10, 2020). I cite our collaborative work because it embodies the community cultural wealth that Habig, Gupta, and Adams argue for informal science education institutions to embrace. Public acknowledgment of the interweaving of intellectual professional space and personal experience ought to be not just for youth participating in science education programs. As science educators and educational researchers, we too bring community cultural wealth to our work. I use these citations to recognize and give value to this form of knowledge building.

In my reflections here, I consider how use of authentic research experiences as a tool for supporting science identity development may be problematic when they do not also include deep changes on the part of educators and institutions. Habig, Gupta, and Adams effectively argue for the value of youths' home experiences and community cultural wealth. Central to their paper is the notion of science identity and pushing against deficit approaches in support of youth in their science identity development. I aim to extend Habig, Gupta, and Adams' work by considering more deeply how informal science educators and institutions need to change their own identities and their very definitions of what science is.

\section{Becoming a science person}

How does someone begin to see themselves as a science person, as a person who has taken up scientific practices and therefore shares an affinity-based identity with a larger community (Gee 2000)? Becoming part of a community, scientific or otherwise, depends on new participants interacting with existing members to gain the skills and knowledge of that community of practice (Lave and Wenger 1991). Recognition by other members of the scientific community is essential to this process and the use of scientific practices and norms is key to this recognition (Bricker and Bell 2014). In their work, examining how women of color navigated entry into science, Heidi Carlone and Angela Johnson note that, "Broadening students' participation in science requires close attention to the kinds of people we ask students to become as they participate in science activities" (Carlone and Johnson 2007, p. 3). So, what kind of science people are these three young people in Habig, Gupta, and Adams' paper being asked to become through their experiences at the museum?

These research experiences include both science acts (doing the investigative work of science) and science talk (using the language of science). Each of the three participants recalled the impact of joining museum research teams and later engaging in research at the collegiate level. For example, Cody, one of the participants, described working on a botany project where he was able to develop his own research question, collect and analyze data, and share those results through a Young Naturalists competition. He links this experience with other research opportunities at the museum and ultimately at college.

These science acts included developing testable questions and collecting, analyzing, and interpreting data-all practices that are codified in current school-based science education standards (Hoeg and Bencze 2017). In this way, schooling practices, which often sharply define who gets characterized as a science person (Allen and Eisenhart 2017), may be reproduced in informal and out-of-school educational spaces where academic standards have increasingly been taken up in youth work (Halpern 2006). The so-called authentic scientific research, like what the participants engaged in, is typically dominated by a 
Eurocentric approach to science that uses systemized methods to count and measure phenomena to help make sense of the world (Hoeg and Bencze 2017). While research experiences like these have the potential to serve as entry points into the scientific community, they can also act as gatekeeping devices if and when they are defined solely by activities that are dominated by Eurocentric norms.

The science talk used during these experiences also serves as both gateway and gatekeeper to becoming a scientific person (Brown 2019) due to the technical language that dominates and frames what counts as "valid science" (Dou and Cian 2020, p. 2). For example, the use of the word "hypothesis" can act as linguistic and cultural capital for entering the scientific community (Archer, Dawson, DeWitt, Seakins, and Wong 2015). Informal science institutions, such as the focal museum in the Habig, Gupta, and Adams paper, are well situated for their role of gateway and gatekeeper because they present themselves, and are seen by the public as, authorities of an unbending disciplinary science to be taken up by visitors and program participants (Dawson 2014b).

\section{But, what kind of science person?}

When scientists, science educators, and science institutions that engage youth have been trained in and primarily use Eurocentric tools and philosophies, the type of science person youth are being asked to become is tightly bounded. I am thinking here of myself and folks like me, who are often asking youth to become more like us. Broadening participationoften called inclusion-may take on what Emily Dawson calls "crusade logic" (Dawson 2019 , p. 5) where we evangelize our own understanding of science as a discipline. For youth to enter this hallowed space, to join us as science people, requires that they adopt dominant norms. Habig, Gupta, and Adams begin to address this type of crusading in their examination of how good intentions that emphasize how the museum benefits youth participants may promote deficit thinking because it fails to acknowledge that the youth have something positive to offer back to the museum. Habig, Gupta, and Adams argue rightfully that informal science education programs instead need to embrace the community cultural wealth of the youth participants.

I want to extend their argument a bit farther. Embracing the community cultural wealth of youth must go beyond respecting and encouraging them to bring their lived experiences from homes and community into their "authentic research" experience. If becoming a "STEM practitioner" is based only on participation in science acts and science talk that are deeply embedded in Eurocentric culture, then we are continuing to hold tightly to ancient boundaries set around science that extend back to Socrates and the early Greek Hippocratics (Schiefsky 2005). If, instead, we aim to adopt science education practices that are culturally responsive and sustaining (Alim and Paris 2017), then we must push deeper and confront the very essence of what science is.

In his ethnographic account of science education in a Yupiaq community, Oscar Kawagley writes: "science is nothing more than curiosity and the observation of how and why things work and how life can be made better through understanding." (Kawagley 2006, p. 101). At first read, this statement seems like it may be easy to reconcile with Eurocentric scientific methods - after all, observation and understanding are foundational practices and goals. But what counts as observation and understanding? This is less simple. Seemingly neutral observation is inevitably clouded by the never neutral gaze (King and Williams, personal communications, April 1-September 10, 2020). 
For example, a common activity I have done with youth is to ask them to make observations of living things, plants, and animals that make up nearby nature. I could then assess their observations and understanding of the world by examining how they conceptualize elements of the world as either living or nonliving. But the binary of living and nonliving, while ubiquitous in science education, is a cultural construct (Bang, Warren, Rosebery, and Medin 2013). A binary and discrete classification system, such as living/nonliving, is foundational to Eurocentric conceptions of observation and understanding. This reaches back to Aristotle's Historia Animalium and Pliny's Natural History. It continues to be the standard in contemporary scientific institutions such as the American Museum of Natural History, the setting for Habig, Gupta and Adams' inquiry. Why does this history matter? I raise these historical connections because my own exploration of the European history of classification as a scientific practice has helped me to recognize that this approach-the approach I was trained in while getting my Master of Science in Botany-reflects my cultural understanding of the world, rather than a fixed set of scientific practices that must be adhered to.

Why is it that soil, which is a combination of decomposing organic matter and weathering rocks, which are themselves formed from the ancient remains of animal shells and plants, is not considered living (Logan 1995)? When we observe soil, are we observing a living thing or a nonliving thing? Perhaps, instead, we might observe soil as something else altogether, as a loving being with which we have a reciprocal relationship (Kimmerer 2013). We might see, then, how soil and soul are connected (King and Williams, personal communications, April 1-September 10, 2020).

\section{Pushing at the edges}

I am not suggesting that there is no value in using discrete categories. In practice, the naming of plants and animals using tools such as Linnean classification does help make sense of the connections between and among many aspects of the world. I have shelves of field guides to all manner of flora and fauna using this approach and I gratefully turn to them often. What I am suggesting is that science educators and institutions need to recognize that practices like this are limited and limiting if presented to youth as the idealized way to be a science person. We might think we are disrupting deficit narratives by enfolding a youth's community cultural wealth into their educational experiences-and still demand that the ultimate adoption of a science identity means entering institutional, unyielding, Eurocentric scientific spaces. This is one of the pitfalls of the 'good intentions' that Habig, Gupta, and Adams discuss. Instead, science educators and institutions need to push at the edges of these bounded spaces so that their very shape begins to change.

If we take the notion of culturally sustaining pedagogy seriously, then we need to reframe authentic scientific research as more than a discipline derived from Eurocentric practices, but as a blend of different traditions and ways of knowing. This is an idea that numerous Indigenous scholars, including Megan Bang, Oscar Kawagley, and Robin Wall Kimmerer, have been theorizing about and practicing. Informal science programs, which are often more flexibly structured to respond to youth interest than traditional school settings, have been shown to push at these edges and create space for youth to negotiate with and transform scientific practices (Barton and Tan 2010). But this may be easier in an afterschool or community-based setting than in a large cultural institution, such as a natural history museum, where what counts as a so-called authentic research experience is tightly 
bounded and defined by the history of Eurocentric science practice. Because these institutions present themselves as and are perceived by the public to be authorities on science, it is imperative that they expand their internal definitions of and presentation about science in their programs (Dawson 2014a).

This means intentionally seeking the moments where ideas, cultures, methods, and practices push up against one another. It means looking for where they contrast and where they are intertwined. This kind of work means embracing the 'and' (King and Williams, personal communications, April 1-September 10, 2020). What if informal science education spaces, from environmental education programs to natural history museums, designed themselves to be deliberately cultivated cultural refugia? The idea of refugia is adopted from climate science where it signifies a protected area where species are able to survive unfavorable conditions, such as glaciation, and then eventually repopulate the larger landscape (Bennett and Provan 2008). How do we create the conditions within informal science education institutions so that they might serve as these refugia-as protected spaces designed for the interrogation and negotiation of science in ways that ultimately circulate out into the larger scientific community? This draws on notions of sanctuary in youth programs, not just for psychological safety, but as critical spaces to support youth identity development (Akiva, Carey, Cross, Delale-O'Connor, and Brown 2017). In this way, science educators and institutions might support young people to not just become successful members within the existing scientific community, but to change the very nature of the field. This is the portal that science and science education must walk through: an examination and transformation of science itself.

\section{References}

Akiva, T., Carey, R. L., Cross, A. B., Delale-O'Connor, L., \& Brown, M. R. (2017). Reasons youth engage in activism programs: Social justice or sanctuary? Journal of Applied Developmental Psychology, 53(August), 20-30. https://doi.org/10.1016/j.appdev.2017.08.005.

Alim, H. S., \& Paris, D. (2017). What is culturally sustaining pedagogy and why does it matter? In H. S. Alim \& D. Paris (Eds.), Culturally sustaining pedagogies: Teaching and learning for justice in a changing world (p. 294). New York, NY: Teachers College, Columbia University.

Allen, C. D., \& Eisenhart, M. (2017). Fighting for desired versions of a future self: How young women negotiated STEM-related identities in the discursive landscape of educational opportunity. Journal of the Learning Sciences, OO(3), 407-436. https://doi.org/10.1080/10508406.2017.1294985.

Archer, L., Dawson, E., DeWitt, J., Seakins, A., \& Wong, B. (2015). “Science capital”: A conceptual, methodological, and empirical argument for extending bourdieusian notions of capital beyond the arts. Journal of Research in Science Teaching, 52(7), 922-948. https://doi.org/10.1002/tea.21227.

Bang, M., Warren, B., Rosebery, A. S., \& Medin, D. (2013). Desettling expectations in science education. Human Development, 55(5-6), 302-318. https://doi.org/10.1159/000345322.

Barton, A. C., \& Tan, E. (2010). We be burnin'! Agency, identity, and science learning. Journal of the Learning Sciences, 19(2), 187-229. https://doi.org/10.1080/10508400903530044.

Bennett, K. D., \& Provan, J. (2008). What do we mean by "refugia"? Quaternary Science Reviews, 27(2728), 2449-2455. https://doi.org/10.1016/j.quascirev.2008.08.019.

Bricker, L. A., \& Bell, P. (2014). "What comes to mind when you think of science? The perfumery!": Documenting science-related cultural learning pathways across contexts and timescales. Journal of Research in Science Teaching, 51(3), 260-285. https://doi.org/10.1002/tea.21134.

Brown, B. A. (2019). Science in the city: Culturally relevant STEM education. Boston, MA: Harvard Education Press.

Carlone, H. B., \& Johnson, A. (2007). Understanding the science experiences of successful women of color: Science identity as an analytic lens. Journal of Research in Science Teaching, 44(8), 1187-1218. https://doi.org/10.1002/tea.20237. 
Dawson, E. (2014a). Equity in informal science education: Developing an access and equity framework for science museums and science centres. Studies in Science Education, 50(2), 209-247. https://doi.org/ $10.1080 / 03057267.2014 .957558$.

Dawson, E. (2014b). "Not designed for us": How science museums and science centers socially exclude low-income, minority ethnic groups. Science Education, 98(6), 981-1008. https://doi.org/10.1002/sce. 21133.

Dawson, E. (2019). Equity, exclusion and everyday science learning. Spokes, 53, 1-13. https://doi.org/10. 4324/9781315266763.

Dou, R., \& Cian, H. (2020). The relevance of childhood science talk as a proxy for college students' STEM identity at a hispanic serving institution. Research in Science Education. https://doi.org/10.1007/ s11165-020-09928-8.

Gee, J. P. (2000). Identity as an analytic lens for research in education. Review of Research in Education, 25, 99-125. https://doi.org/10.3102/0091732x025001099.

Halpern, R. (2006). Confronting "The Big Lie": The need to reframe expectations of after-school programs. In F. Stott (Ed.), Critical issues in after-school programming (pp. 111-137). Chicago, IL: Herr Research Center for Children and Social Policy, Erikson Institute.

Hoeg, D. G., \& Bencze, J. L. (2017). Values underpinning STEM education in the USA: An analysis of the Next Generation Science Standards. Science Education. https://doi.org/10.1002/sce.21260.

Kawagley, O. (2006). A Yupiaq worldview: A pathway to ecology and spirit (2nd ed.). Long Grove, IL: Waveland Press Inc.

Kimmerer, R. W. (2013). Braiding sweetgrass. Minneapolis, MN: Milkweed Editions.

Lave, J., \& Wenger, E. (1991). Situated learning: Legitimate peripheral participation. Cambridge: Cambridge University Press.

Logan, W. B. (1995). Dirt: The ecstatic skin of the earth. New York: Riverhead Books.

Roy, A. (2020, April). The pandemic is a portal. Financial Times. Retrieved May 8, 2020, from https:// www.ft.com/content/10d8f5e8-74eb-11ea-95fe-fcd274e920ca.

Schiefsky, M. (2005). Introduction to on ancient medicine. In Hippocrates on ancient medicine: translated with introduction and commentary. Brill.

Publisher's Note Springer Nature remains neutral with regard to jurisdictional claims in published maps and institutional affiliations.

Marijke Hecht is Assistant Professor of Recreation Park and Tourism Management at Penn State Greater Allegheny. Her research focuses on environmental interest development and interactions between and among human and nonhuman nature in urban greenspaces. Her work draws on her interdisciplinary background in environmental education, community-based ecological design, learning sciences, and naturalist practices. 